\title{
Commitment Of Part-Time Students In Germany: An Empirical Analysis
}

Christoph W. Busch, Fontys International Business School, The Netherlands

Serkan Akbay, FOM - University of Applied Science, Germany

Clemens Jäger, FOM - University of Applied Science, Germany

\begin{abstract}
The following empirical research investigated the difference of several form of commitment of part time students to their employer. Therefore, this study based on the three component model of Allen \& Meyer (1990). Most of the previous empirical researches investigated the commitment of employees within an organization. The measurement of commitment of part time students to their employer is largely unexplored and build the research gap of the following empirical research. The objectives of the work are to present the previous scientific findings of the three components model of Allen \& Meyer and to answer the question if and what extent the commitment of part time students in Germany changed during their study time.
\end{abstract}

To test possible differences of commitment, the questionnaire with 24 items was used. 231 part-time students participated in the survey. In addition to the statistical basics, the differences of commitment were found by using a two sample t-test. A key finding of this research is that students at the end of their study time have a lower commitment to their employer as students at the begin of their study time.

Keywords: Commitment; Three Component Model; Part-Time Students

\section{INTRODUCTION}

( ualified, well-educated and motivated employees are an essential success factor for the strategy development and -implementation and therefore have to be taken into consideration when observing a longterm success of organizations. A study of Burstedde, Kolev \& Matthes (2018) found out in a simulation that the lack of qualified employees affects the gross domestic product in Germany by a negative percentage rate of 0.9 . This lack of qualified employees already leads in the past years to a more competitive scenery for the hiring and retention of well-educated, talented and motivated employees which is also named as the phenomenon war of talents (Chambers, Foulon, Handfield-Jones, Hankin \& Michaels III, 1998). If these employees will leave an organization, this leads to the effect that organizations have a loss of knowledge and competence which could have a significant influence to the organizations. Next to several other influencing factors also the commitment of an employee is directly link with a turnover. Allen \& Meyer state that "[...] employees who are strongly committed are those who are least likely to leave the organization" $(1990$, p. 1). A special target group on which this paper will focus, is defined as a group of employees which combine their work within an organization with a part-time study.

Based on the findings of von Wedemeyer (2016) the amount of German working employees with a part-time study is still increasing since years. Based on the authors findings, more than 300 institutions offer approximately 2,700 different study programs.

Normally, such part-time students are doing their apprenticeship or their regular work within an organization. This indicates, that these employees are qualified staff. Due to the fact, that they take part in an extra-occupational study these kind of employees regularly have a higher education entrance qualification which leads to the conclusion, that they are well-educated. Gaedke, Covarrubias Venegas, Recker \& Janous (2011) state, that extra-occupational students have to deal with multiple strains consisting out of study, work and family or leisure activities which indicates a high motivation. 


\section{LITERATURE REVIEW}

The term commitment in general can be defined as the subjectively perceived bonding between an individual employee with its organization (Felfe, 2008; Frieg \& Borkhoff, 2013; Kanning, 2017; van Dick, 2004). A more precise definition of commitment has been defined by Allen \& Meyer in the 1990s. These authors classify commitment into three different aspects: affective commitment, continuance commitment, and normative commitment (Allen \& Meyer, 1990).

Concerning Mowday, Porter \& Steers affective commitment is "[...] a strong belief in and acceptance of the organizational goals and values, a willingness to exert considerable effort on behalf of the organization and a strong desire to maintain membership in the organization" (1982, p. 27). In other words, affective commitment can be defined as an emotional attachment to an organization (Allen \& Meyer, 1990; Landry \& Conte, 2010; Lee, Allen, Meyer \& Rhee, 2001). Referring to Kanning (2017) an employee has a high level of affective commitment if he is proud to work for an organization.

Referring to Gong, Law, Chang, Xin (2009) the term continuance commitment relates to the tendency to leave or remain in an organization on the basis of the perceived costs of leaving it (Landry \& Conte, 2010; Shore \& Wayne, 1993). Based on the findings of Kanning (2017) the continuance commitment is not based on emotional decisionmaking. Employees with a low continuance commitment will stay within an organization as long as this employment brings more benefit than leaving the organization. As soon as there is a new opportunity with better job conditions, for example a higher salary or a better career perspective, the employer will leave the organization as a consequence of rational decision-making (Kanning, 2017; Vandenberghe \& Tremblay, 2008; Vandenberghe, Panaccio \& Ayed, 2011).

Wiener (1982) defines normative commitment as a function of internalized employees' normative beliefs. Obalola, Aduloju \& Olowokudejo point out that "[...] the normative view of the construct (commitment) conceives organizational commitment as a desire to maintain membership in an organization because of a strong felt moral obligation" (2012, p. 44). This strong moral obligation as a reason to remain in an organization is also the key aspect for Kanning (2017). In his opinion the moral obligation could arise from several aspects. It is rather a question of whether the employee feels an obligation towards an organization because of the behavior of this organization in the past. For example, if the organization paid job trainings, or paid reliably the salary of the employee (Kanning 2017).

Allen \& Meyer (1990) come to the conclusion that the connection between the affective commitment and the continuance commitment is weak while normative commitment and affective commitment are correlated to each other on a significant level. Moreover, the continuance commitment and normative commitment have a significant correlation (Meyer \& Allen 1990). Several other studies proof this assumption in different research fields and come to the same conclusions (Meyer, Stanley, Herscovitch \& Topolnytsky, 2002; Meyer et al. 2012).

There are many more studies about commitment and subsequently numerous meta-analyses. Meyer et al. (2002) as well as Tett \& Meyer (1993) analyzed the correlation between the different variants of commitment and job satisfaction. Kanning (2017) summarizes that both studies come to the result that a high level of job satisfaction has a strong relationship with the affective commitment. In addition, a correlation between the normative commitment and job satisfaction is recognizable. Based on the findings of Kanning (2017) this correlation is on a lower level while a negative correlation between the continuance commitment and the job satisfaction could be observed.

Several meta-analyses investigate the correlation between commitment and job performance (Cohen \& Hudecek 1993; Cooper-Hakim \& Viswesvaran 2005; Jaramillo, Mulki \& Marshall, 2005; Meyer et al., 2002; Ng 2015). Kanning (2017) figures out, that all studies show a positive connection between the job performance and the affective commitment. Furthermore, a study of Wright \& Bonett (2002) shows that the general organizational commitment and the job performance have a positive relationship for new employees within an organization. Moreover, the study come to the conclusion, that this correlation declines with increasing years of employment. As a result of these findings, Kanning (2017) come to the conclusion, that the longer employees are employed within a company the less close is the connection between their commitment and their performance. 
The results of the study of Riketta (2002) is able to show, that the correlation between job performance and affective commitment was at significantly stronger by employees with extra-role performance as opposed to in-role performance as well as employees which were performance assessed by self-ratings as opposed to supervisor ratings. Last but not least the study shows that the correlation between the job performance and the affective commitment as significant stronger by "white-collar workers as opposed to blue-collar workers" (Riketta 2002, p. 257). Kanning (2017) interprets this result of Riketta's (2002) study in the way that the connection between job performance and affective commitment is higher for employees with higher qualifications than those with lower qualifications.

Due to the fact that employees who are also part-time students and which are in total, the minority of students' wordwide, limited research is available concerning the commitment of these special group of employees. A study of Turner, Jordan \& DuBord (2005) conclude that "the higher student employee's affective commitment, the more they desired to maintain employment” (Wells \& Lower, 2016, p. 39).

Based on the previous explanations, a research gap of the investigation of the three components model of Allen \& Meyer (1990) and part time students could be identified. Therefore, the following research question was formulated:

How does a part time study affect the degree of the affective, continuance and normative commitment?

\section{RESEARCH HYPOTHESIS}

Regarding to the above mentioned framework, the following hypothesis was formed:

H1: The duration of the part time study change the affective commitment.

H2: The duration of the part time study change the continuance commitment.

H3: The duration of the part time study change the normative commitment.

During the following chapter, various hypotheses are formulated to ensure the adequate use of the individual empirical instruments. Therefore, hypothesis $\mathrm{H} 0$ and $\mathrm{H} 1$ are formed for each of the individual test instruments in the following process.

\section{DATA AND METHODOLOGY}

To ensure an adequate solution of the formed research question, the following data obtaining and sample definition has been chosen. Because part time students are in the focus of the investigation, the instrument of a class room questionnaire represent the basis of the study. The students study at the FOM University of Applied Sciences. The FOM is with more than 46,000 students and 29 study centers, Germany's biggest private institute of higher education and has been accredited by the German Council of Science and Humanities (FOM, 2017). Due to the possibility of a direct access to the students, 233 part time students participated in the survey and represent the data sample. The basic population of the research is based on information of the authority of statistic of the government of the federal state North-Rhine Westphalia. The number of the basic population is 133,585 students (S. Dederichs, personal communication, July 3, 2018).

Due to the comparison between students in the first and last years of study time, a group of 135 part time students within the first years (FY) and a group of 98 part time students within the last time (LY) were formed. The surveyed students are structured as shown in table 1.

Table 1. Sample structure

\begin{tabular}{l|l}
\hline Students FY & 135 \\
\hline Students LY & 98 \\
\hline = Total number of surveyed students & $\mathbf{2 3 3}$ \\
\hline Incomplete data records & $\mathbf{2}$ \\
\hline = Total number of considered surveyed students & $\mathbf{2 3 1}$ \\
\hline
\end{tabular}


Before starting with the empirical investigation, a pre-test of the developed method with 30 students were tested. Based on the pre-test, minor changes of the variables were changed, e.g. the enquiry of the exact year of birth. The changes were implemented in the final questionnaire. Simultaneously, first evidences could be generated. A Cronbach's alpha level of the pre-test was $65 \%$. Based on the number of participants of 30 of the pre-test, a sufficient consistency of the questionnaire was given and enable the application of the main test. The standard error based on a confidence level of $95 \%$, a basic population of 133,585 students, a accepted alpha level of $5 \%$ and the given sample size is $6.46 \%$.

Another component of the study is the questionnaire. The questionnaire essentially based on the Three Component Model (TCM) of Allen \& Meyer (1990). The TCM is operationalized through the 3 forms of commitment. Allen \& Meyer measured each form of commitment by 8 items. The variables were operationalized by a five point Likert scale.

\section{RESULTS AND DISCUSSION}

In order to obtain results, the statistical program $\mathrm{R}$ was used. The data set consists of 24 items ( 8 for each form of commitment) plus 7 variables to obtain general information about the students. Additionally, for each form of commitment new the variables AC, ACSB, ACSE, CC, CCSB, CCSE, NC, NCSB, NCSE were constructed.

First, an outlier analysis were performed. Therefore, the variables AC, CC and NC are presented as boxplots. Figure 2 shows the boxplots of the three variables.

It can be seen that the variables contain 3 outlier values. The dataset was adjusted by an outlier clearing. Therefore, all values of the variables $\mathrm{AC}, \mathrm{CC}$ and $\mathrm{NC}>30$ have been cleared.

Figure 1. Boxplots of the variables

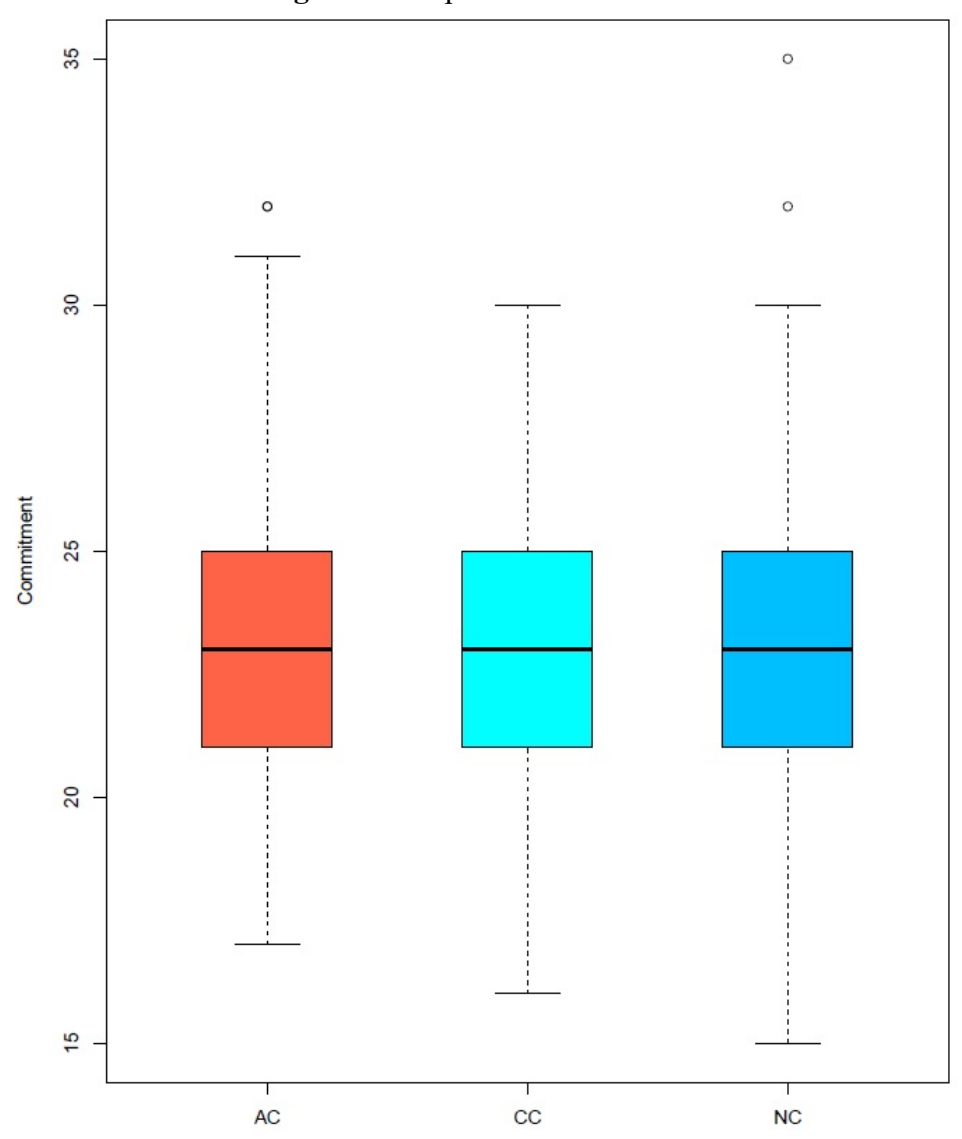


It can be seen that the variables contain 3 outlier values. The dataset was adjusted by an outlier clearing. Therefore, all values of the variables $\mathrm{AC}, \mathrm{CC}$ and $\mathrm{NC}>30$ have been cleared.

Table 2. Descriptive statistics

\begin{tabular}{|c|c|c|c|c|c|c|c|}
\hline \\
\hline Variable & Min. & Median & Mean & Max. & SD & Skewness & Kurtosis \\
\hline \multicolumn{8}{|c|}{ Values with outliers } \\
\hline ACSB & 17.00 & 23.00 & 23.56 & 32.00 & 2.84 & 0.25 & -0.23 \\
\hline ACSE & 17.00 & 23.00 & 23.06 & 32.00 & 2.99 & 0.50 & 0.15 \\
\hline CCSB & 18.00 & 23.00 & 23.63 & 30.00 & 2.65 & -0.05 & -0.51 \\
\hline CCSE & 16.00 & 23.00 & 22.51 & 29.00 & 2.80 & -0.21 & -0.41 \\
\hline NCSB & 15.00 & 23.00 & 23.44 & 30.00 & 2.97 & -0.06 & -0.25 \\
\hline NCSE & 15.00 & 23.00 & 23.05 & 35.00 & 3.44 & 0.43 & 0.90 \\
\hline \multicolumn{8}{|c|}{ Values without outliers } \\
\hline ACSB & 17.00 & 23.00 & 23.44 & 29.00 & 2.70 & 0.09 & -0.54 \\
\hline ACSE & 17.00 & 23.00 & 22.81 & 29.00 & 2.67 & 0.15 & -0.51 \\
\hline NCSE & 15.00 & 23.00 & 22.68 & 29.00 & 2.96 & -0.19 & -0.14 \\
\hline
\end{tabular}

Table 2 shows that there is no substantially differences between the median and the mean. The values of the kurtosis suggest that the observed value are in the near of the mean value. The skewness values of ACSB, ACSE, NCSE are $>$ 0 , so that the value distributions are right-skewed. The skewness values of CCSB, CCSE, NCSB are $<0$, so that the value distributions are left-skewed. After an outlier clearing the skewness values suggest that ACSB and ACSE don't change the degree of skewness. The skewness of the variable NCSE changed the degree of skewness from a rightskewed to a weak left skewed distribution.

Another relevant act is the testing of the internal consistency of the used questionnaire. Therefore, a reliability analysis was used to detect the Cronbach alpha level. The raw alpha level of our data set is $82 \%$ and is in line with previous scientific investigations regarding to the three components model (Felfe, Schyns \& Tymon, 2014; Shore \& Wayne, 1993; Westphal \& Gmür, 2009).

After the descriptive statistic for the variables, a shapiro wilk test was performed to test the normal distribution of the variables. The hypothesis is:

H0: The values are normal distributed

H1: The values are not normal distributed

The results of the shapiro wilk test are described in the following Table 3.

Table 3. Results of the shapiro wilk test for the variables

\begin{tabular}{l|l|l|l}
\hline Variable & W-value & p-value & \multicolumn{1}{c}{ Normal distributed } \\
\hline ACSB & 0.9793 & 0.0376 & H0 confirmed $\rightarrow$ Normal distributed \\
\hline ACSE & 0.96945 & 0.02207 & H0 confirmed $\rightarrow$ Normal distributed \\
\hline CCSB & 0.97465 & 0.01268 & H0 confirmed $\rightarrow$ Normal distributed \\
\hline CCSE & 0.97685 & 0.08105 & H0 confirmed $\rightarrow$ Normal distributed \\
\hline NCSB & 0.9816 & 0.06506 & H0 confirmed $\rightarrow$ Normal distributed \\
\hline NCSE & 0.97605 & 0.07036 & H0 confirmed $\rightarrow$ Normal distributed \\
\hline
\end{tabular}

The $p$-value of each variable is greater than the generally accepted p-value of $1 \%, 5 \%$ and $10 \%$. The variables ACSB, ACSE, CCSB fulfil the shapiro wilk test with the $5 \%$ significance level. The other variables fulfil the shapiro wilk test with the accepted level of $10 \%$. Therefore, a normal distribution of the values is given on a significant level and ensure the application of the following instruments.

The next step was a correlation analysis. Hereby, the outcome shows the linear relationship between the variables actual semester and AC, actual semester and $\mathrm{CC}$ and actual semester and $\mathrm{NC}$. To test a correlation, the correlation 
analysis of Karl Pearson (Cleff, 2011; Hatzinger, Hornik, Nagel \& Maier, 2014) was used. The following test hypothesis was formed:

H0: The variables actual semester and $\mathrm{AC}, \mathrm{CC}$, and $\mathrm{NC}$ are independent.

H1: The variables actual semester and $\mathrm{AC}, \mathrm{CC}$ and $\mathrm{NC}$ are related.

Table 4. Results of the correlation analysis

\begin{tabular}{c|c|c|c|c}
\hline Variable & t-value & df & p-value & Correlation \\
\hline Actual semester/AC & -0.13727 & 231 & 0.8908 & -0.009031162 \\
\hline Actual semester/CC & -3.6512 & 231 & 0.0003229 & -0.2335833 \\
\hline Actual semester/NC & -0.92289 & 231 & 0.357 & -0.06060979 \\
\hline
\end{tabular}

The Pearson product-moment correlation detected the following results presented in table 4 . The p-value correlation test actual semester and CC is smaller than the accepted alpha level of $1 \%$. Therefore, the $\mathrm{H} 0$ can be disconfirmed. The p-value of the correlation actual semester and the $\mathrm{NC}$ is greater than the alpha level of $1 \%$, but smaller than the alpha level of $10 \%$. The correlation is weak.

The final step of the empirical investigation was to perform a two sample t-test which is shown in table 5 . The test answered the question, if there is a difference of the means of two data sample. The hypothesis is:

H0: The mean values of the samples are equal.

H1: The mean values of the sample are unequal.

Table 5. Results of the two sample t-test

\begin{tabular}{c|c|c|c|c|c|c}
\hline Variable & T & df & p-value & $\begin{array}{c}\text { Mean variable } \\
\text { study start }\end{array}$ & $\begin{array}{c}\text { Mean study } \\
\text { end }\end{array}$ & Difference \\
\hline ACSB / ACSE & 1.2737 & 202.63 & 0.2042 & 23.55556 & 23.06122 & -0.49434 \\
\hline CCSB / CCSE & 3.0832 & 202.01 & 0.0023 & 23.62963 & 22.51020 & -1.11943 \\
\hline NCSB / NCSE & 0.8952 & 202.01 & 0.3718 & 23.43704 & 23.05102 & -0.38602 \\
\hline
\end{tabular}

With a 99 percent confidence interval, the $\mathrm{H} 0$ for CCSB/CCSE can be disconfirmed for the relationship CC during the study time. There is a difference of the degree of commitment during the study time. The difference of commitment for the relationship ACSB/ACSE and NCSB/NCSE during the study time is not significant.

The hypothesis ' $\mathrm{H} 1$ : The duration of the part time study change the affective commitment' could not be confirmed by the accepted level of $1 \%, 5 \%$ and $10 \%$. The ' $\mathrm{H} 2$ : The duration of the part time study change the continuance commitment.' could be confirmed. The p-value of 0.002334 is $<$ than the accepted level of $1 \%$. The 'H3: The duration of the part time study change the normative commitment.' could not be confirmed by the accepted level.

\section{CONCLUSION}

The results of the study and the identified research gap confirm the above mentioned previous literature, which empirically examined the Allen \& Meyer theorem. In conclusion, the differences of the mean between the formed variables are significant, even though partial marginally. The measurement of the research problem via the used questionnaire is adequate and is proven with a high alpha value. In addition, the correlation analysis of the employer support and the several forms of commitment recognize significant relationships. Part time students at the end of their study time have a lower commitment to their employers. Based on the findings of this study, organizations are recommended to deal intensively with their high potential employees in order to strengthening and expanding their position in the war of talents. It is recommended, that organizations review and, if necessary, adapt existing measures of their commitment management to their employees. At the same time, the study implies that further factors influence the commitment and thus offer area for further investigations. Since the duration of the study and the commitment were tested within the scope of the study, further influencing factors were not examined. There are several factors that 
can influence the commitment. For example, the salary, the working environment, the image of the employer or the opportunities for an individual development by their employer are actually not investigated and offer further research fields.

\section{AUTHOR BIOGRAPHIES}

Christoph W. Busch (MBA) is a PhD-candidate at the UCAM - Universidad Católica De Murcia, Murcia, Spain and a lecturer at Fontys International Business School, Fontys University of Applied Sciences, Venlo, The Netherlands and the FOM - University of Applied Science, Essen, Germany. E-Mail: c.busch@fontys.nl

Serkan Akbay (M.Sc.) is a PhD-candidate at the UCAM - Universidad Católica De Murcia, Murcia, Spain and a lecturer at the FOM - University of Applied Science, Essen, Germany. He also is a relationship manager for corporates in a credit institution in Germany. E-Mail: serkan.akbay@fom-net.de

Clemens Jäger is a Prof. Dr. and Dean at the FOM - University for Economics and Management in Essen, Germany. He also lectures for many years at Colleges and universities in Australia, the Netherlands and Spain. In its functions he is responsible for various national and international cooperation's between companies and universities. Within the scope of his research activities the graduate economist and computer scientist under with early warning indicators in the framework of the restructuring of companies. E-Mail: clemens.jaeger@fom.de

\section{REFERENCES}

Allen, N. J., \& Meyer, J. P. (1990). The measurement and antecedents of affective, continuance and normative commitment to the Organization. Journal of Occupational Psychology, 63, 1-18.

Burstedde, A., Kolev, G.; Matthes, J. (2018). Wachstumsbremse Fachkräftemangel (Report No. IW-Kurzbericht 27/2018). Retrieved from Cologne Institute for Economic Research website: https://www.iwkoeln.de/fileadmin/user_upload/Studien/Kurzberichte/PDF/2018/IWKurzbericht_2018_27_Wachstumsbremse_Fachkraefteengpaesse.pdf.

Chambers, E. G., Foulon, M., Handfield-Jones, H., Hankin, S. M., \& Michaels III, E. G. (1998). The war for talent. The McKinsey Quarterly, 3, 44-57.

Cleff, T. (2011). Deskriptive Statistik und moderne Datenanalyse: Eine computergestützte Einführung mit Excel, PASW (SPSS) und STATA [Descriptive statistics and modern data analysis: A computer-aided introduction with Excel, PASW (SPSS) and STATA] (2nd ed.). Wiesbaden: Gabler Verlag.

Cohen, A., \& Hudecek, N. (1993). Organizational commitment-turnover relationship across occupational groups. Group and Organizational Management, 18, 188-213.

Cooper-Hakim, A., \& Viswesvaran, C. (2005). The construct of work commitment: Testing an integrative framework. Psychological Bulletin, 131, 241-259.

Felfe, J. (2008). Mitarbeiterbindung [Staff retention]. Göttingen: Hogrefe Verlag.

Felfe, J., Schyns, B. \& Tymon A. (2014). The impact of university students' commitment on in- and extra-role performance. Journal of applied research in higher education, 6(1), 149-167.

Frieg, P., and Borkhoff, C. (2013, December 5). Bochumer Commitment Inventar (BOCOIN): Befunde zu Validität, Geschlecht, Alter, Organisationsgröße und Branchen [Research report] Retrieved from http://www.testentwicklung.de/mam/forschungsbericht_bocoin_02.pdf

FOM (2017). Die FOM. Retrieved from https://www.fom.de/die-fom.html

Gaedke, G., Covarrubias Venegas, B., Recker, S., \& Janous, G. (2011). Vereinbarkeit von Arbeiten und Studieren bei berufsbegleitend Studierenden [Compatibility of work and study for part-time students]. Zeitschrift für Hochschulentwicklung, 6(2), 198-213.

Gong, Y., Law, K. S., Chang, S., \& Xin, K. R. (2009). Human Resources Management and Firm Performance: The Differential Role of Managerial Affective and Continuance Commitment. Journal of Applied Psychology, 94(1), $263-275$.

Hatzinger, R., Hornik, K., Nagel, H., Maier, M.J. (2014). R-Einführung durch angewandte Statistik [R - Introduction through applied statistics] (2nd ed.). Hallbergmoos: Pearson.

Jaramillo, F., Mulki, J. P. \& Marshall, G. W. (2005). A meta-analysis of the relationship between organizational commitment and salesperson job performance: 25 years of research. Journal of Business Research, 58, 705-714.

Kanning, U. (2017). Personalmarketing, Employer Branding und Mitarbeiterforschung: Forschungsbefunde und Praxistipps aus der Personalpsychologie [Personnel marketing, employer branding and employee research: research findings and practical tips from personnel psychology]. Berlin: Springer-Verlag.

Landry, F. J., \& Conte, J. M. (2010). Work in the 21st century: An introduction to industrial and organizational psychology (3rd 
ed.). Hoboken, NY: John Wiley \& Sons.

Lee, K., Allen, N. J., Meyer, J. P., \& Rhee, K.-Y. (2001). The Three-Component Model of Organisational Commitment: An Application to South Korea. Applied Psychology: An international review, 50(4), 596-614.

Meyer J. P., Stanley, D. J., Herscovitch, L., \& Topolnytsky, L (2002). Affective, Continuance, and Normative Commitment to the Organization: A Meta-analysis of Antecedents, Correlates, and Consequences. Journal of Vocational Behavior, 61(1), 20-52.

Meyer, J. P., Stanley, D. J., Jackson, T. A., McInnis, K. J., Maltin, E. R., \& Sheppard, L. (2012). Affective, normative, and continuance commitment levels across cultures: A meta-analysis. Journal of Vocational Behavior, 80, $225-245$.

Mowday, R. T., Porter, L. W., \& Steers, R. M. (1982). Employee Organizations: The Psychology of Commitment, Absenteeism and Turnover. New York, NY: Academic Press.

$\mathrm{Ng}$, T.W.H. (2015). The incremental validity of organizational commitment, organizational trust, and organizational identification. Journal of Vocational Behavior, 88, 154-163.

Obalola, M., Aduloju, K., \& Olowokudejo, F. (2012). Organizational Commitment and Corporate Ethical Values: Exploring the Nexus between Employees' Psychological Contract and Firms' Ethical Behaviour in the Nigerian Insurance Industry. Journal of Management and Sustainability, 2(1), 43-56.

Riketta, M. (2002). Attitudinal organizational commitment and job performance: a meta-analysis. Journal of Organizational Behavior, 23, 257-266.

Shore, L. M., \& Wayne, S. J. (1993). Commitment and employee behavior: Comparison of affective commitment and continuance commitment with perceived organizational support. Journal of Applied Psychology, 78(5), 774-780.

Tett, R. P., \& Meyer, J. P. (1993). Job satisfaction, organizational commitment, turnover intention, and turnover: Path analysis based on meta-analytic findings. Personnel Psychology, 46, 259-293.

Turner, B. A., Jordan, J. S., \& DuBord, R. R. (2005). Retaining student workers: The importance of organizational commitment. Recreational Sports Journal, 29, 117-126.

Van Dick, R. (2004). Commitment und Identifikation in Organisationen [Commitment and identification in organisations]. Göttingen: Hogrefe Verlag.

Vandenberghe, C., \& Tramblay, M. (2008). The Role of Pay Satisfaction and Organizational Commitment in Turnover Intentions: A Two-Sample Study. Journal of Business and Psychology, 22(3), 275-286.

Vandenberghe, C., Panaccio, A., \& Ayed, A. K. B. (2011). Continuance commitment and turnover: Examining the moderating role of negative affectivity and risk aversion. Journal of Occupational and Organizational Psychology, 84, 403-424.

Von Wedemeyer, J. (2016. October 7). Das Feierabend-Studium. Süddeutsche Zeitung. Retrieved from https://www.sueddeutsche.de

Wells, J. E., \& Lower, L. M. (2016). Part-time student employees' commitment: The role of culture types. Recreational Sports Journal, 40(1), 36-45.

Westphal, A., \& Gmür, M. (2009). Organisationales Commitment und seine Einflussfaktoren: Eine qualitative Metaanalyse [Organizational commitment and its influencing factors: A qualitative meta-analysis]. Journal für Betriebswirtschaft, 59(4), 201-229.

Wiener, Y. (1982). Commitment in Organizations: A Normative View. Academy of Management Review, 7(3), 418-428.

Wright, T. A., \& Bonett, D. G. (2002). The Moderating Effects of Employee Tenure on the Relation Between Organizational Commitment and Job Performance: A Meta-Analysis. Journal of Applied Psychology, 87(6), 1183-1190. 